Pamiętnik Literacki 2021, 3, s. 163-178
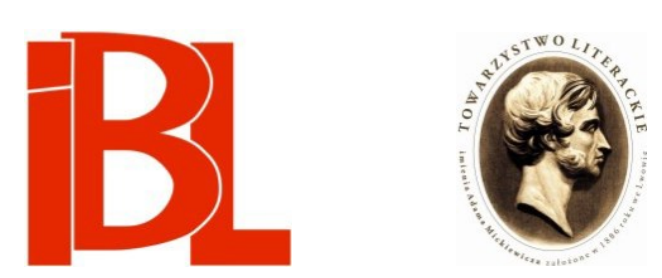

\title{
Norwid i sztandary. Przyczynki do interpretacji i historii recepcji wiersza „Żydowie polscy" - dwugłos
}

Anita Jarzyna, Katarzyna Kuczyńska-Koschany 


\title{
NORWID I SZTANDARY PRZYCZYNKI DO INTERPRETACJI I HISTORII RECEPCJI WIERSZA „ŻYDOWIE POLSCY” - DWUGŁOS*
}

\author{
Przechodniu powiedz Polsce żeśmy polegli w jej służbie \\ synowie jej Polacy Żydzi i Rusini \\ Przechodniu powiedz że krew nasza była jednej barwy ${ }^{1}$.
}

W artykule pragniemy sprawdzić (po części „sobą”) współczesność Norwidowskiego wiersza, przyjrzeć się wybranym strategiom aktualizowania go, wskazać na konteksty interpretacyjne, jakie on wywołuje, oraz na konteksty ideowe, światopogladowe, które niejako jego wywołują, a także zwrócić uwagę na zmieniające się uwarunkowania odczytań samej tytułowej formuły Żydowie polscy i jej zmodernizowanego, powszechnie przyswojonego w polszczyźnie, wariantu. Innymi słowy jeszcze, interesuje nas to, jak rezonuje zainicjowany w utworze dialog polsko-żydowski, w jakich konceptualizacjach znajduje rozwinięcie.

\section{1}

Ty jesteś w Europie, poważny Narodzie

Żydowski, jak pomnik, strzaskany na Wschodzie,

Swoimi gdy złamki wszędzie się rozniesie,

Na każdym hieroglif unosząc odwieczny -

A człowiek północny, w sosnowym gdy lesie

Napotka cię, odbłysk zgaduje słoneczny

Ojczyzny! - co kędyś w niebieskim lazurze

Jak Mojżesz, się w wodzie pławiła Nilowéj! -

I mówi: „Jest wielkim, kto bywał tak w górze,

I upadł tak nisko, i milczy jako wy".

2

Północne my syny $z$ włosami płowemi, Wschodowej historii my śnieżne obłoki Za kabał granica, od razu, wprost z ziemi Patrzący na niebios przybytek wysoki: Jak Agar synowie - przez kraju istotę, Jak Sary synowie - przez ojców robotę;

* Inicjały umieszczone przy tytułach poszczególnych części artykułu sygnalizuja, która z autorek zabiera głos.

1 A. Ka mi eń s ka, Notatnik rzymski. III. W: Poezje zebrane. Pod red. W. Kr u s zew s ki e go. T. 2. Lublin 2020, s. 87. 
My pierwej niż inni - my wcale inaczéj

Pojrzeliśmy ku wam, bynajmniej z rozpaczy:

Boć herbem gdy $\mathrm{z}$ wami szlachetny się łamał,

Krzyż bywał w przełomie tym - i on nie kłamał!

3

Aż oto, że dzieje pozornie są za m ęt,

Gdy w gruncie są: siła i ładność szeroka! -

Aż oto, że dzieje sa jako testament,

Którego cherubin dogląda $\mathrm{z}$ wysoka -

Więc znowu Machabej na bruku w Warszawie

Nie staną w dwuznacznej z Polakiem obawie.

- I kiedy mu ludy bogatsze na świecie

Dawały nie krzyże, za które się kona,

Lecz z których się błyszczy - cóż? przeniósł on przecie:

Bezbronne, jak Dawid, wyciagnąc ramiona! -

4

Poważny narodzie! cześć tobie w tych, którzy

Mongolsko-czerkieskiej nie zlękli się burzy -

I Boga Mojżeszów bronili wraz z nami

Spojrzeniem rycerskim, nagimi piersiami,

Jak starsi w historii, co, ręką na dzicze

Kiwnąwszy z wysoka, wołają: „Dotrwałem!

Choragwi się badam, nie chłopy twe liczę,

Bo kiedyś był nicość, ja mleko już ssałem -

Naturę znam dawniej! - więc przeklnę wędzidła

I staniesz na koniu jak pastuch - bez by dła”2.

\section{Figura dzierżawcy $[\mathrm{AJ}]$}

W związku z kwestiami, na które chcę zwrócić uwagę, szczególnego i przewrotnego znaczenia nabierają znane słowa Norwida:

Pan Tadeusz: ulubiony i słynny poemat narodowy polski, w którym jedyną poważną i s e ri o figura jest kto?... Żyd (Jankiel) ${ }^{3}$.

Zacząć jednak warto od przypomnienia podstawowych ustaleń na temat wątków żydowskich w twórczości autora Quidama. Otóż w przenikliwym, przeglądowym artykule z 1992 roku poświęconym temu zagadnieniu Jacek Leociak z filologiczną czujnością rekonstruował zręby poglądów poety, rozpięte między obserwacjami społecznymi a koncepcjami historiozoficznymi. Kluczowa wydaje się następująca diagnoza literaturoznawcy:

Norwid - krytyczny i twórczy użytkownik języka oraz wytrawny znawca Biblii - musiał zdawać sobie doskonale sprawę $z$ uwarunkowań językowego obrazu Żyda w polszczyźnie. Można stwierdzić, że w tym zakresie jezzyk Norwida odzwierciedla wszystkie charakterystyczne zjawiska i tendencje panujace w języku ogólnym.

2 C. Norwid, Żydowie polscy. 1861. W: Pisma wszystkie. Zebrał, tekst ustalił, wstępem i uwagami krytycznymi opatrzył J. W. Gom uli cki. T. 1: Wiersze. Cz. 1. Warszawa 1971, s. 339-340.

3 C. Norwid, list do W. Cybulskiego, z 9 I 1967. W: jw., t. 9: Listy 1862-1872, s. 272. 
Około 50\% wszystkich użyć wyrazu „Żyd” i jego pochodnych ma zabarwienie mniej lub bardziej negatywne, podczas gdy niecałe $10 \%$ występuje w kontekstach pozytywnych. Podobnie więc jak w języku ogólnym swego czasu, Norwid częściej posługuje się tym słowem w sensie pejoratywnym niż neutralnym, a rzadko $\mathrm{w}$ sensie pozytywnym ${ }^{4}$.

W gruncie rzeczy rozproszona w ciaggu dziesięcioleci narracja Norwida, choć obejmuje rozmaite gatunki literackie i użytkowe, a także sporą reprezentację stereotypowych postaci oraz zdecydowanie mniej zróżnicowane obrazowanie, towarzyszące opisom żydowskiego świata, okazuje się raczej spójna, wartościowanie w jej ramach zaś jest właściwie jednoznaczne i uzależnione od gotowości Żydów do przejścia na katolicyzm. W związku z czym żadnego $z$ omawianych przykładów Leociak nie wyodrębnia jako odstającego od zarysowanego ujęcia, co nie znaczy, że nie niuansuje swoich analiz. Dotyczy to również wiersza Żydowie polscy, z jego patriotycznym przesłaniem zainspirowanym zdarzeniem z 8 IV 1861, które zostało w tekście głęboko zaszyfrowane. Miało ono miejsce podczas połączonej z kościelną procesją warszawskiej demonstracji przeciw carskiemu zaborcy, kiedy to jeden $z$ jej uczestników, Michał Landy, 17-letni gimnazjalista, Żyd, podniósł krzyż po tym, jak upuścił go przewodzacy zgromadzeniu zakonnik, zamordowany przez rosyjskie wojsko. W rezultacie młody mężczyzna również stracił życie. Kontekstowa interpretacja tego utworu, do czego jeszcze wrócę, staje się w dużej mierze deziluzyjna, prowadzi w istocie do zrewidowania znaczeń przypisanych przywołanemu w nim czynowi.

Kontury, jakie Leociak nadał Norwidowskiej narracji, rejestr przykładów, które wydobył i pogrupował, poniekąd uświadamiają, że ten wątek w myśli poety domaga się lektury całościowej. W większości przywoływanych przypadków bowiem pojedyncze wzmianki wyjęte $z$ pism autora Vade-mecum wydają się mało wyraziste, a wręcz niesamodzielne, toteż można by argumentować, iż zostały przez niego podporządkowane innym treściom i problemom, więc nie należy na ich podstawie wyciaggać zbyt daleko idacych wniosków, zwłaszcza że niekiedy pojawiają się w odległych historycznie realiach i jako takie mogłyby uchodzić za przywoływane na prawach cytatu. Leociak zresztą odnotowuje tę wątpliwość, wspominając o oscylacji między utożsamieniem a dystansem ${ }^{5}$. Mimo to jednak - przyszły wówczas - badacz Zagłady (co nie wydaje się bez znaczenia) dowodzi zasadności wpisywania refleksji poety we wspierający społeczne antagonizmy i uprzedzenia kod wyobraźni zbiorowej, ugruntowywany jeszcze w następnych dekadach - przed odzyskaniem przez Polskę niepodległości i potem ${ }^{6}$.

Podsumowując swoje analizy, literaturoznawca umieszcza refleksje Norwida, wprawdzie jedynie sygnalnie, na szerszym tle:

\section{J. Le o ci a k, „Strzaskana całość” - Norwid o Żydach. „Teksty Drugie” 1992, nr 5, s. 29.}

Ibidem, s. 34.

Zob. A. C ała, Asymilacja Żydów w Królestwie Polskim (1864-1897). Postawy, konflikty, stereotypy. Warszawa 1989. - Ideologia antysemicka 1848-1914. Wybór tekstów źródłowych. Oprac. A. Ż bikowski. Warszawa 1994. Warto nadmienić, że na podobnej zasadzie jak Norwid inny poeta, także wyróżniający się nowatorskimi zapatrywaniami na język, J. Czechowicz, posługiwał się właściwym dla swoich czasów antysemickim słownictwem. Zob. A. J a rzy n a, Rejestry przemocy. Usuwanie Żydów z języka Czechowicza. „Poznańskie Studia Polonistyczne. Seria Literacka” t. 22 (2013). 
Postawa prozelityzmu i tendencje do zastępowania judaizmu chrześcijaństwem były w ówczesnym dialogu polsko-żydowskim bardzo charakterystyczne. W jakimś sensie wychodziły im naprzeciw tendencje asymilacyjne wśród Żydów ${ }^{7}$.

Wobec czego tym bardziej warto sprawdzić, czy i jak przyswajano poglądy Norwida na ten temat. Kiedy jego diagnozy tudzież propozycje zostały rozpoznane? W jakich okolicznościach się do nich odwoływano? Zasadniczo ślady recepcji poety w tym względzie okazują się zastanawiająco skromne. Niemniej w 1933 roku, na łamach prasy w związku $z$ obchodami 50 rocznicy śmierci Norwida, miała miejsce tyleż szczególna, co symptomatyczna dyskusja dotycząca jego twórczości - dyskusja, w której właściwie nie doszło do rzeczywistej wymiany racji czy zdań ukierunkowanej na próbę porozumienia, każda ze stron ograniczyła się bowiem do tego, że ogłosiła swoje stanowisko, nie dbała, by ustosunkować się do wypowiedzi oponenta. Ten - wiele wskazywałoby, że mało znaczący i właściwie nieodnotowywany dotąd - epizod w dziejach recepcji autora Zwolona ${ }^{8}$, obfitującej w dużo żywsze polemiki (również o podłożu politycznym), pozwala jednak lepiej przyjrzeć się nieodosobnionej przecież praktyce wykorzystywania słów Norwida na „sztandarach światopoglądowych"9.

Polemiczny impuls, wprawdzie zawoalowany, wyszedł od redakcji endeckiego tygodnika „Myśl Narodowa”, która rocznicę śmierci Norwida postanowiła uczcić, poświęcając mu w całości jeden numer (datowany na $21 \mathrm{~V}$ ). W otwierającym go artykule Stanisław Cywiński dowodził, że światopogląd poety tożsamy jest $z$ „chrześcijańskim nacjonalizmem” ${ }^{10}$. Tę koncepcję - bez wątpienia kluczową dla całej publikacji $-\mathrm{z}$ różnych perspektyw rozwijali również autorzy innych tekstów: Władysław Arcimowicz, piszący o specyfice patriotyzmu Norwida, Rajmund Bergel, charakteryzujący jego przekonania polityczne, czy Zygmunt Falkowski, komentujący poemat Quidam. Ponadto upomniano się o - mniej narzucające się w tym kontekście - niedostatecznie rozpoznane problemy twórczości plastycznej (Wiktor Podolski) oraz biografii poety (Zygmunt Wasilewski) ${ }^{11}$. Najpewniej miał ów numer ostatecznie potwierdzić prawo środowiska Stronnictwa Narodowego do identyfikowania się z Norwidem, do obwołania go jednym z patronów ideowych

Le ociak, op. cit., s. 46.

8 Znamienne, że tego wątku nie rejestruje M. Inglot, autor obszernej antologii Norwid. Z dziejów recepcji twórczości (Wybór tekstów, oprac., wstęp M. In glot. Warszawa 1983, s. 230-267), dokumentującej krytyczno- i historycznoliteracką recepcję Norwida, w której osobny, wydzielony blok tworzą artykuły powstałe przy okazji obchodów 50 rocznicy śmierci poety. Ciekawe i zastanawiające, że wśród wybranych przez badacza publikacji pochodzących zarówno z miesięczników, tygodników, jak i dzienników, reprezentujących różne środowiska („Drogę”, „Myśl Narodową”, „Robotnika”, „Dziennik Polski”, ,Kurier Wileński”, „Kurier Literacko-Naukowy”), nie znalazły się artykuły ukazujące się wówczas na łamach prasy żydowskiej. Niewykluczone, rzecz jasna, że na decyzję o pominięciu owych tekstów w książce wydanej w 1983 roku wpływ miały względy cenzuralne.

9 W szerszej perspektywie omawiał to zjawisko L. Ka miński (Romantyzm a ideologia. Główne ugrupowania polityczne Drugiej Rzeczypospolitej wobec tradycji romantycznej. Wrocław 1980).

10 S. Cywiń s ki, Aktualność Norwida. „Myśl Narodowa” 1933, nr 23, s. 1.

11 Swoją drogą, Z. W a silew ski (Na widowni. Jw., s. 11) krytykuje w tym artykule, odnosząc się do młodopolskiej recepcji Norwida, tendencję do uwspółcześniania go, a przecież właściwie podobną strategię stosowali inni autorzy tygodnika, uznający poglądy poety za zbieżne z ideologią Stronnictwa Narodowego. 
ugrupowania; wszak już w poprzednich latach poświęcano mu sporo uwagi, publikowano również jego listy w opracowaniu zarówno Zofii Szmydtowej, jak i Stanisława Pigonia. Zresztą z podobną intencją - wskazania czy raczej skonstruowania światopoglądowych sprzymierzeńców - w poprzednim roku złożono numer o twórczości Stanisława Wyspiańskiego (przy okazji 25 rocznicy śmierci), a w kolejnych miesiącach 1933 roku niemało pisano o Janie III Sobieskim (w związku z 250-leciem odsieczy wiedeńskiej przypadającym 16 IX).

Tydzień po ukazaniu się numeru Norwidowskiego w jednej ze stałych rubryk periodyku, zatytułowanej $\mathrm{Na}$ marginesie, pojawił się następujący anonimowy komentarz:

Wśród ogółu prasy w Polsce, w sposób mniej lub więcej uroczysty czczącej Norwida w pięćdziesięciolecie Jego zgonu, wyróżniły się „Wiadomości Literackie”, które o rocznicy norwidowskiej nie zamieściły dosłownie nawet jednego zdania. Jakoś zapomniano o tym zupełnie, wśród nawału spraw aktualnych, jak propaganda spędzania płodu, homoseksualizmu, walki z Hitlerem... Nikt nie pomyślał jakoś, ot, zdarza się, roztargnienie... A to brzydko tak nie umieć odwdzięczyć się poecie za jego piękny wiersz Żydowie polscy... ${ }^{12}$

Wskazując na ten wiersz, redakcja tygodnika sygnalizowała, być może, że nie zamierza ignorować tekstu Norwida, który stał się wyrazem poglądów potencjalnie niewygodnych dla środowiska polskich nacjonalistów, ale zarazem zdawała się sugerować, że tytułowi bohaterowie utworu (czy też ich potomkowie) nie zasłużyli na owo, najwyraźniej przedwczesne, uznanie poety. Znamienne przy tym, że autorzy rocznicowego numeru „Myśli Narodowej” wyjątkowo oszczędnie odnosili się do wątków żydowskich w twórczości Norwida, jakby w obawie, że bardziej szczegółowe dociekania wymagałyby uwzględnienia niuansów, w konsekwencji zaś uzgodnienia bądź ukrycia rozbieżności między poglądami poety a antysemickim programem ideologów pisma. Możliwe, że dlatego jedyna wzmianka na ten temat pojawiła się w artykule o Quidamie - Falkowski tłumaczac, z czego wynikało zainteresowanie autora poematu starożytnością i jaką rolę odgrywało w utworze, wyzyskując stereotyp i zarazem nawiązując do słów Norwida $z$ jego przytoczonego wcześniej listu do Marii Trębickiej, pisał: „sztuka grecka i jędrne prawodawstwo rzymskie, i okrutna żarliwość żydowska w wierze, połączona $z$ chytrością zawodowych przekupniów oto jest mleko macierzyńskie naszej cywilizacji”" ${ }^{13}$. Zasadniczo, z uwagi na walory perswazyjne, za korzystniejsze mogły być uznawane właśnie takie, mniej zobowiązujące odwołania, niewymagające objaśnień, a łatwo poddające się instrumentalizacji. Podobnie trzy tygodnie później, Jan Rembieliński, komentując na łamach pisma toczacy się w maju 1933 proces przeciw członkom Obozu Wielkiej Polski inicjatorom antysemickich zamieszek w Radziłowie (doszło do nich 23 III 1933 ${ }^{14}$ ), nawiązał do zacytowanego w norwidowskim numerze „Myśli Narodowej” fragmentu poematu A Dorio ad Phrygium, w którym mowa o niemalże odwiecznej obecności Żydów na polskiej wsi. Dalece zniekształcając znaczenie owych słów, publicysta

$12 * * *$, ,Myśl Narodowa” 1933, nr 24, s. 15.

13 Z. Falkows ki, O poemacie „Quidam”. Jw., nr 23, s. 4. Zob. C. N orwid, list do M. Trębickiej, z maja 1854. W: Pisma wszystkie, t. 8: Listy 1839-1861, s. 213.

14 Zob. M. Try c zy k, Miasta śmierci. Sasiedzkie pogromy Żydów. Warszawa 2015, s. 168. 
przekonywał, że obserwacje poety tłumaczą, dlaczego wszelkie (także nacechowane przemoca) działania zmierzające do usunięcia tej społeczności z życia gospodarczego w Polsce zasługują na poparcie i podziw ${ }^{15}$.

Tymczasem redakcja „Wiadomości Literackich” nie zareagowała na wspomnianą zaczepkę; być może uznano, że, podobnie jak inne tego rodzaju prowokacje, należy ją zignorować. Za to dokładnie tego samego dnia, gdy w „Myśli Narodowej” pismu Mieczysława Grydzewskiego zarzucano rzekome zaniedbania, czyli $28 \mathrm{~V}$, „Nasz Przegląd” opublikował pokaźny, jak na normy owego dziennika, artykuł Maksymiliana Boruchowicza (znanego później jako Michał Borwicz) Cyprian Norwid ( $w$ 50-ta rocznicę śmierci). Krytyk, kreśląc portret niekoniecznie wyłącznie okolicznościowy, skupił się na oryginalności stylu poetyckiego i koncepcji sztuki swojego bohatera oraz na intelektualnym wymiarze jego poszukiwań artystycznych, zrezygnował zaś z jakichkolwiek odniesień do zapatrywań autora Vade-mecum na relacje polsko-żydowskie. Obok tekstu umieszczono jednak wiersz Żydowie polscy, na prawach sygnału, który - sugerowano, być może - nie wymaga komentarza ${ }^{16}$. Dopiero niewiele ponad dwa miesięce później - 6 VIII - w „Naszym Przeglądzie” ukazał się artykuł Jehudy Warszawiaka, zatytułowany Kamil Cyprian Norwid a Ży$d z i$, w punkcie wyjścia aluzyjnie polemiczny wobec wymowy rocznicowego numeru „Myśli Narodowej”:

stało się poniekąd misją tradycyjną u fachowców literackich z obozu endecji, aby zawsze gdy Polska obchodzi rocznicę śmierci czy jubileusz swych wielkich synów - wykazać, że należą lub, gdyby żyli, należeliby do obozu endeckiego ${ }^{17}$.

W dalszej części niezbyt długiego tekstu autor starał się odzyskać Norwida dla swojego środowiska, mianując go w tym względzie „spadkobierca” Adama Mickiewicza i formułując argumenty - słabo jednak udokumentowane odniesieniami do konkretnych tekstów - mające potwierdzić ową tezę. Co najciekawsze, publicysta bez większych zastrzeżeń przyjął krytykę Norwida wymierzoną w Żydów, uznając ją za przejaw troski o ich nadwątlone życie duchowe. Prawdopodobnie w taki sposób próbował wypracować kompromis, pozwalający przedstawiać poetę jako sprzymierzeńca społeczności żydowskiej w Polsce ${ }^{18}$. Ta, do pewnego stopnia, interwen-

J. Rembielińs ki, Na widowni. „Myśl Narodowa” 1933, nr 26, s. 10.

M. B or u c how i c z, Cyprian Norwid (w 50-tą rocznicę śmierci). „Nasz Przegląd” 1933, nr z 28 V, s. 12 .

J. W a rszawiak, Kamil Cyprian Norwid a Żydzi. Jw., nr z 6 VII, s. 10. Warto odnotować, że podobnie o zawłaszczaniu Norwida przez środowisko nacjonalistyczne pisano na łamach „Drogi”, zarówno w artykułach zamieszczonych w poświęconym poecie monograficznym numerze opublikowanym w 1933 roku, jak i parę miesięcy później - w felietonie W. K u b a c ki e g o Pojubileuszu Norwida („Droga” 1934, nr 7/8). Zob. Ka mińs ki, op. cit., s. 39-40.

Warto podkreślić, że wspomniany artykuł stanowi część szerszej strategii redakcji prosyjonistycznego dziennika, na którego łamach bardzo często ukazywały się teksty prezentujące polskich pisarzy - XIX-wiecznych i współczesnych - ich związki z kulturą żydowską oraz refleksje na temat relacji $z$ tą społecznością. Także w ten sposób upominano się o równość obywatelską. Ponadto twierdzi znawczyni „Naszego Przeglądu”, M. Szabłows ka-Zaremba (O polsko-żydowskich kontaktach literackich na łamach "Naszego Przegladu” w latach 1918-1939. W zb.: Naruszone granice kulturowe. O kondycji ludzkiej $w$ dwóch przestrzeniach: polskiej i żydowskiej XX wieku. Red. M. Szabłowska-Zaremba, B. Walęciuk-Dejneka. Lublin 2013, s. 228-229) - 
cyjna publikacja nie była pierwsza wypowiedzią na łamach pisma poświęconą owym kwestiom. Kilka lat wcześniej ukazał się krótki, niezbyt udany - zarówno koncepcyjnie, jak i retorycznie - szkic Jakuba Cungego, który „pierwiastek żydowski” w twórczości Norwida, zapowiedziany w tytule tekstu, sprowadził do wyliczenia przykładów paru motywów zaczerpniętych przez poetę z Biblii hebrajskiej ${ }^{19}$. Zresztą również wywód Warszawiaka opierał się częściowo na podobnych przesłankach.

Ostatecznie to właśnie tekst Warszawiaka spotkał się z odpowiedzią w „Wiadomościach Literackich", ogłoszoną zresztą dość późno, bo dopiero 10 IX w artykule M. H. Piątkowskiego Norwid a Żydzi. Dyskutując z publicystą „Naszego Przeglądu”, krytyk pośrednio odniósł się też do działań redakcji „Myśli Narodowej”, dowodząc, że jego metoda, polegająca na wyrywaniu pojedynczych fraz z kontekstu, głównie z Promethidiona, jest nie mniej tendencyjna niż zabiegi stosowane przez autorów czasopism „narodowych”. W zasadzie przekonująco zakwestionował wszystkie ustalenia oponenta. Sam zaś, sondując ten problem, doszukiwał się mniej jednoznacznych motywacji poety:

Jeśli tedy Norwid tu i ówdzie odzywał się z sympatią o Żydach, to nie dlatego, że się odzywał o Żydach, lecz że się odzywał - chrześcijanin. $Z$ czego nie wynika, aby poeta miał ustosunkowywać się pozytywnie do dorobku kulturalnego Żydów ${ }^{20}$.

Dość nieoczekiwane posunięcie Piątkowskiego, który postanowił nie zwracać się bezpośrednio do zawłaszczających Norwida środowisk nacjonalistycznych i sympatyków Stronnictwa Narodowego, lecz polemizować z publicystami zapewne bliższymi sobie światopoglądowo, również instrumentalizującymi twórczość poety, demaskuje fiasko starań obu stron sporu. Wynika ono, oczywiście, stąd, że nie o autora Vade-mecum chodziło dyskutantom, lecz o kapitał symboliczny, jaki wniósłby on, stając się ich patronem. Jednak ponieważ kategorie, którymi operował Norwid, nie pasowały do doraźnych ujęć zorientowanych na płytkie aktualizowanie, publicyści zdradzali pewną bezradność wobec jego tekstów, o czym najdobitniej świadczy stosunek do wiersza Żydowie polscy, przez jednych i drugich wymienianego, ale praktycznie pozostawianego bez komentarza (pisał Warszawiak - co zresztą ironicznie podchwycił Piątkowski - że „wprost brak mu 〈Norwidowi - przyp. M. H. P.〉 słów, aby wyrazić waleczność i wytrzymałość 〈? - przyp. M. H. P.〉 Żydów”). Zaproponowane przez Piątkowskiego krytyczne ujęcie tych problemów wskazuje na zaprzepaszczony potencjał dyskusji, która mogłaby przecież skłonić do namysłu nad podłożem kulturowym ówczesnych antagonizmów, a która wyczerpała się wraz z ustaniem okolicznościowych publikacji i nie doczekała się żadnego rozstrzygnięcia.

Śladów, wprawdzie niezbyt wyraźnych, podobnej refleksji można jeszcze doszukać się w obszernej rozprawie Juliusza Feldhorna „Pomnik strzaskany”. (Motywy żydowskie w twórczości Cypriana Norwida), opublikowanej w podwójnym letnim numerze „Miesięcznika Żydowskiego”, więc niemal w tym samym czasie, gdy uka-

w latach trzydziestych „dla redaktorów dziennika ważki stał się fakt badania opinii polskich środowisk twórczych, gdyż ich zdanie było papierkiem lakmusowym ówczesnej sytuacji”.

19 J. C u n ge, Pierwiastek żydowski w twórczości C. Norwida. 1888-1928. „Nasz Przegląd” 1927, nr z 11 XII, s. 6.

20 M. H. Piątkowski, Norwid a Żydzi. „Wiadomości Literackie” 1933, nr 39. Na stronie: http:// retropress.pl/wiadomosci-literackie/norwid-a-zydzi (data dostępu: 11 I 2021). 
zał się szkic Piątkowskiego. We wstępie autor, jak poprzednicy, nie wymieniając poszczególnych tytułów, wspomniał o praktyce zawłaszczania poety przez prasę codzienna. Ale mimo że deklarował zamiar przeprowadzenia wyważonej, obiektywnej analizy wątków, które nazwał „żydoznawczymi”, również nie uniknął miejscami stronniczej prezentacji problemu, tyle że nie opartej już na kilku przykładach, lecz osadzonej w generalnie rzetelnej interpretacji większej partii materiału. Do takich odstępstw należy choćby treść adnotacji dodanej na końcu artykułu, aluzyjnie polemicznej, być może, wobec publikacji Piątkowskiego w „Wiadomościach Literackich” (niewykluczone bowiem, że „Miesięcznik Żydowski” z tą rozprawą ukazał się nieco później, niż sugerowałaby numeracja pisma) - chodzi o stwierdzenie krytyka, jakoby ostatnia w twórczości Norwida wypowiedź na temat Żydów, czyli nowela „Ad leones!", była reprezentatywna dla jego ujęcia owych kwestii ${ }^{21}$. Feldhorn, nie przystając na taką diagnozę, chciał - zdaje się - uniknąć formułowania nazbyt krytycznego wygłosu swojego wywodu i przede wszystkim nie doprowadzać do ujednoznacznienia poglądów poety; za ich syntezę uznał wiersz Żydowie polscy, do którego w zakończeniu artykułu odniósł wszystkie wyszczególnione w swej rozprawie aspekty omawianego problemu:

Cześć historyka dla dziejów biblijnych, entuzjazm wieszcza dla postaci Mojżesza i Proroków, zastrzeżenia wierzacego katolika, mistyka i historiozofa, filozoficzne zamyślenie nad losem najstarszego w Europie narodu. Wszystko to splata się w jeden patetyczny węzeł myśli i uczuć, z których tryska objawienie, ogromny, łukiem tęczy nad wiekami rozpostarty symbol:

Tragedia Izraela znajdzie „oczyszczenie” w tragedii Polski22 ${ }^{22}$

Czytając ten fragment, nawet przez pryzmat krytycznej lektury wiersza, można uznać, iż autor artykułu postawił trafną diagnozę, nie potrafił jednak (albo nie chciał?) zmierzyć się z konsekwencjami swojego rozpoznania - prawdopodobnie dlatego wybiórczo przytaczał i komentował urywki utworu, by nie dopowiadać, że wizja relacji społecznych, którą konstruuje Norwid, ma charakter hierarchiczny, została narzucona jednej grupie przez drugą. Co Piątkowski, omawiając wiersz, stwierdza wprost: ,tylko chrzest był, według Norwida, jednym istotnym sposobem uobywatelnienia Żydów"23. Krytyk, nie mając w twórczość Norwida (wówczas wciąż jeszcze znaną połowicznie) takiego wglądu, jaki posiadają jej współcześni badacze,

21 Z kolei M. In gl ot (Nad artykułem Cypriana Norwida „Ż̇ydy“ i mechesy”. W: Drogami pielgrzyma. Studia i artykuły o twórczości „Czwartego wieszcza”. Lublin 2007, s. 277-292) twierdzi, że punktem dojścia poglądów Norwida w tej kwestii był tekst z 1882 roku „Żydy” $i$ mechesy, pomyślany jako artykuł prasowy, a napisany w reakcji na pogromy, do jakich dochodziło wówczas w Rosji. Badacz podkreślał, że w omawianym szkicu poeta korygował swoje wcześniejsze wypowiedzi, w których powtarzał szkodliwe antysemickie przesądy na temat mordu rytualnego, a rzeczownika „Żyd” używał głównie w znaczeniu pejoratywnym, w tym tekście natomiast odnosił się krytycznie do owego zwyczaju językowego, przy czym twierdził, że to sami Żydzi powinni wpłynąć na zmianę uzusu - „wybrzmienie właściwe nadać i utrzymać izraelskiemu-imieniowi” (C. Norwid, „Żydy” i mechesy. W: Pisma wszystkie, t. 6: Proza, s. 648). Niemniej i tu Norwid podtrzymywał swoje przekonania - stanowiące sedno jego zapatrywań na tę kwestię - o potrzebie nawrócenia Żydów na katolicyzm.

22 J. Feldh orn, „...Pomnik strzaskany”. (Motywy żydowskie w twórczości Cypriana Norwida). „Miesięcznik Żydowski” 1933, nr 7/8, s. 25-26.

23 Piątkowski, op. cit. 
doszedł do podobnych wniosków jak Leociak. Obydwaj też zwrócili uwagę na wyjątkową na tle innych wypowiedzi poety tonację wiersza Żydowie polscy, podyktowana przez wzruszenia patriotyczno-religijne ${ }^{24}$, przysłaniajacce uprzedzenia autora, który jednak nie zmienił swoich przekonań. Leociak przypomina, że ten utwór nie był zresztą odosobnioną reakcją na warszawskie manifestacje w roku $1861 \mathrm{z}$ udziałem Żydów (kilka anonimowych tekstów odnoszących się do tamtych zajść odnotowuje Jan Winczakiewicz $\mathrm{w}$ antologii Izrael $w$ poezji polskiej25). Nadto badacz podkreśla, że w jednym $z$ listów Norwid przywoływał inną, mniej patetyczną scenę Z wydarzeń z 8 IV, wokół których osnuł swój wiersz:

$\mathrm{Na}$ jarmark poczet artylerii prowadzono i pluton piechoty; Żydowie w czamarach czarnych po drodze pytają: „Gdzie armaty wiodą, bo jeżeli na jarmark, to oni i tu kupić je gotowi”.

W Warszawie w pełnych zebraniach na pół widnych, bo w publicznej kawiarni, Żydowie polscy wołają tam i owdzie: „Ile kosztować by mogła Cytadela? - jeśli około piętnaście milionów, to dobrze - dać możemy"26.

Poza narzucającym się kontrastem między anegdotyczną opowieścią a przypowieścią (odpowiednio i wyraźnie przyporządkowanymi do sfer profanum oraz sacrum w spektrum postaw patriotycznych ${ }^{27}$ ) rzecz również w tym, że autor wybrał epizod, który miałby zaświadczać o potrzebie, jeśli nie wymogu, budowania solidarności opartej na zacieraniu różnic, na postępującej homogenizacji wyznaniowej. Słusznie podkreślał Piątkowski, iż w utworze od politycznych zdecydowanie ważniejsze są treści religijne. Do tych diagnoz Leociak dopowiada, że dziś - w świetle ustaleń Soboru Watykańskiego II - propozycja Norwida okazuje się anachroniczna, niezgodna $z$ nauczaniem Kościoła ${ }^{28}$. Czy wobec tego należy uznać omawiany wiersz wyłącznie za literacki dokument tamtych czasów, poprzestać na lekturze przez pryzmat XIX-wiecznych realiów i kategorii? Czy można jednak - wziąwszy w nawias kwestie niezgodności $z$ aktualną doktryną - czytać ten utwór, w szerszej perspektywie, jako paradygmatyczny dla pewnego sposobu określania relacji polsko-żydowskich (na płaszczyźnie kulturowej nierzadko utożsamianych zresztą z relacjami katolicko-żydowskimi)? Wiązałoby się to zarazem ze wznowieniem, jak i przekierowaniem dyskusji z 1933 roku poza wyłącznie doraźne rozpoznania.

Proponuję na koniec rozważenie kilku przesłanek przemawiających za obraniem takiego - uniwersalizującego nieco wymowę wiersza - trybu lektury. Trzeba od razu zastrzec, że ujęcie to respektuje kontekst historyczny, a głównie społeczno-kulturowy, w jakim utwór powstał, ale stara się wydobyć wpisane w niego, wówczas niekoniecznie rozpoznawane czy problematyzowane, właściwe dla relacji polsko-

Zob. A. B r ze g- P i s k o z u b, Zmierzch romantyzmu. Zarys poezyi powstania styczniowego. Lwów 1913, s. 61-64. - Z. S t e fa n ow s k a, Spór o powstanie. W: Strona romantyków. Studia o Norwidzie. Lublin 1993.

Izrael $w$ poezji polskiej. Zebrał J. Winc zaki ew ic z. Paryż 1958, s. 101-105. Zob. J. Detka, Żyd. Hasło w: Stownik literatury polskiej XIX wieku. Red. J. Bachór z, A. Kow alc zy kowa. Wrocław 1991.

C. N or wi d, list do A. Jełowickiego, z końca października 1861. W: Listy 1839-1861, s. 452.

Zob. Le o ciak, op. cit., s. 39.

Ibidem, s. 42-45. 
-żydowskich dychotomie oraz napięcia, które trwale ciążą na rodzimym imaginarium, choć bywają na różną skalę uruchamiane bądź wyciszane.

Przede wszystkim zaryzykowałabym tezę, że Norwid poniekąd przechwycił doświadczenie Żydów. Przejął zdarzenie, niewątpliwie mające wielki potencjał symboliczny dla jego uczestników, i je zreinterpretował, jeśli nie sformatował, wedle własnej koncepcji historiozoficznej. Za sprawą częściowej transpozycji manifestacji warszawskiej na realia biblijne poeta dokonał swoistej nobilitacji współczesnych mu Żydów, utrzymując zarazem dystans wobec nich jako nie do końca rzeczywistych, raczej mitycznych figur ${ }^{29}$, nie zrezygnował więc $z$ podkreślania ich obcości, różnicy, która podlega tu - subtelniejszemu wprawdzie niż w innych wypowiedziach wartościowaniu. Odbija się w tym wierszu dialektyka (dawnej) świetności, wielkości i (współczesnej) małości, właściwa dla Norwidowskiej refleksji na temat Żydów ${ }^{30}$. Uznaniu zaś dla ich zaangażowania we wspólne wyzwoleńcze działania towarzyszy jednak przekonanie o własnej - Polaków - wyższości, o głębszym wtajemniczeniu $\mathrm{w}$ sens dziejów. Zgodnie $\mathrm{z}$ takim podejściem inkluzyjny gest, $\mathrm{w}$ utworze tożsamy z ustępstwem, winien wychodzić od grupy mniejszościowej - aspirującej.

Trudno nie zauważyć, że cały tekst oparty jest na silnie eksponowanej i do końca nieprzezwyciężonej opozycji my-oni ${ }^{31}$, nie osłabia jej bynajmniej tytułowa fraza, zreszta głęboko przyswojona w warstwie frazeologicznej języka polskiego. Norwidowska formuła „Żydowie polscy” zwraca najpierw uwagę niespotykaną dziś forma mianownika liczby mnogiej rzeczownika „Żyd”, ale nie ona wydaje się kluczowa, wszak w polszczyźnie XIX wieku uchodziła za neutralną, jako podstawowa (w stosunku do współczesnej „Żydzi”) notuje ją słownik Samuela Bogumiła Lindego ${ }^{32}$ oraz wydany w 1861 roku „słownik wileński” 33 , Norwid zresztą posługiwał się nią wielokrotnie. Warto natomiast zastanowić się nad całą kolokacją, która zdaje się w wierszu wynikać ze szczególnych uwarunkowań (co dodatkowo potwierdza wyeksponowana data roczna), tzn. tytułowi bohaterowie musieli udowodnić, że zasłużyli na owo miano. Więcej, sugeruje się, że dla niego powinni wyrzec się swojej tożsamości - w imię tego, co reprezentuje i oferuje im krzyż (zgodnie zresztą ze

O pewnej enigmatyczności tych obrazów świadczy polemika A. Sandauera z komentarzem J. W. G o$\mathrm{m}$ u li c k i e g o do wiersza Żydowie polscy, zamieszczonym w Dodatku krytycznym, opublikowanym jako tom 2 opracowanej przez niego edycji Dzieł zebranych (C. N orwid, Wiersze. Cz. 2. Warszawa 1965, s. 620). Wprawdzie niektóre z uwag krytyka zdają się uzasadnione, zwłaszcza odnoszące się do zbyt jednoznacznej, wręcz parabolicznej wykładni wersów: „Jak Agar synowie - przez kraju istotę / Jak Sary synowie - przez ojców robotę”, uważanych przez edytora za „aluzję do narodu polskiego rozbitego na emigrację i na tych, którzy pozostali w kraju" (A. Sandauer, Norwid o Żydach polskich. „Literatura” 1978, nr 2, s. 11). Zastanawiające i niejasne są jednak intencje związane z powstaniem tej polemiki, jako że została ona ogłoszona 7 lat po publikacji w 1971 roku Pism wszystkich poety, gdzie wydawca nie powtórzył już owych budzących wątpliwości objaśnień. Zob. Le ociak, op. cit., s. 45.

Interesująca w tym kontekście i symptomatyczna dla pewnego typu lektury wiersza wydaje się obserwacja Z. Łapińskiego (Norwid. Wyd. 2. Kraków 1984, s. 40), który zwraca uwagę na wyraźnie obecny w utworze podmiot zbiorowy - „my”, i objaśnia: „to znaczy ci wszyscy Polacy, którzy przyłączają się do poetyckiego hołdu złożonego współmieszkańcom swej ziemi”. Przy czym jednocześnie badacz nie dostrzega, że tak ukonstytuowana wspólnota nadal sytuuje się - wprawdzie nie wrogo, lecz z dystansem - w opozycji do Żydów jako „nie-naszych”, innych, „onych”.

33 Stownik języka polskiego. Wydany staraniem M. Orgelbra nda. T. 2. Wilno 1861, s. 2277. 
wspomnianą w tekście tradycją I Rzeczypospolitej - nadawania szlachectwa konwertytom). I nawet jeśli krzyż byłby tu wyłącznie symbolem kulturowym, a nie znakiem wiary, to nie jest on symbolem wspólnie uzgodnionym, lecz raczej symbolem dostosowania się, asymilacji, która po raz kolejny okazuje się konceptem budzącym wątpliwości, o znamionach kolonizatorskich. Co ciekawe, wynika stąd, że przywołane w wierszu imię Mojżesza, wspólnego proroka, nie wystarczyło w potencjalnie analogicznej jak krzyż funkcji jednoczącej. W dalszej perspektywie utwór uświadamia też pewną znamienną wieloznaczną asymetrię między frazami „Polak-katolik” a „Żyd polski” (gramatycznie i metaforycznie rzecz ujmując: między relacją współrzędności a podrzędności; co oczywiście, w wariancie nieopresyjnym, może również skutkować bardziej swobodnym rozumieniem przynależności).

W 1989 roku we wstępie do katalogu krakowskiej wystawy „Żydzi - polscy” jej kurator, tłumacząc, z czego wynika nietypowy kształt tytułu ekspozycji, odwoływał się do formuły Norwida, powtórzonej ponad 80 lat później przez Juliana Tuwima, zastrzegając, że od ich czasów zmieniło się wiele -

dziś już nie możemy powtórzyć w tytule użytej przez nich nazwy grupy mniejszościowej. To przede wszystkim Żydzi. Ale ich własny los na tej ziemi należy także do losu narodu polskiego. W tytule powinny zabrzmieć oba te wyrazy, ale zamiast wymawiać je jednym tchem, zawiesimy go pomiędzy nimi. A więc: „Żydzi - polscy” ${ }^{34}$.

To rozszczelnienie, wytrącające $z$ nawyków percepcyjnych, przeciwdziałające bezrefleksyjnym automatyzmom, zapisane zresztą za pomocą zabiegu kojarzącego się z Norwidowską interpunkcją, dziś wydaje się równie, jeśli nie bardziej, zasadne. Rzecz jasna, nie chodzi o to, by w następstwie zrezygnować z posługiwania się tą opisową formułą (i analogicznymi, jak „Żydzi niemieccy” lub „Żydzi węgierscy”), powszechnie zresztą występującą (także w nazwach własnych, choćby Muzeum Historii Żydów Polskich), warto jednak zastanawiać się, jakie zobowiązania i na kogo może ona nakładać. Innymi słowy, czy w przypadku niektórych użyć tej frazy zawarty w niej przymiotnik dzierżawczy nie pociaga za sobą konieczności zapłacenia zbyt wysokiej ceny za udział w polskości?

Tę kwestię podniosła na swój sposób Zofia Trojanowiczowa, autorka interpretacji wiersza Norwida opracowanej z myślą o uczniach i uczennicach szkół średnich. Kreśląc przykładowy scenariusz lekcji poświęconej temu utworowi, literaturoznawczyni proponuje - jak zastrzega - kontrowersyjne zestawienie go z Campo di Fiori Czesława Miłosza. Sugeruje, że późniejszy wiersz z obrazem Żydów „ginących, samotnych" 35 w 1943 roku w Warszawie poniekąd weryfikuje przesłanie utworu Norwida - Trojanowiczowa chciałaby w tym kontekście rozważyć przede wszystkim koncepcję „dziejów jako testamentu”, pyta o związek między postępowaniem zbiorowości a jej tradycją ${ }^{36}$. Uczona nie dopowiada wszelako, czy wobec tego „biedni

M. R. [M. Ro stwor ow s ki], Wstęp. W: Żydzi - polscy. Czerwiec - sierpień 1989. Wystawę i kat. przygot. D. De c [i in.]. Zarys historii Żydów polskich napisali M. Horn, J. To mas zewski. Kraków br., s. 7.

35 Cz. Miło s z, Campo di Fiori. W: Wiersze wszystkie. Kraków 2011, s. 193.

36 Z. Tr oj a n ow i c z o w a, „Dzieje sajako testament”. Wiersz „Żydowie polscy. 1861” C. K. Norwida. W zb.: Glosariusz od starożytności do pozytywizmu. Materiały do kształcenia literackiego $w$ szkole średniej. Red. T. Patrzałek. Wrocław 1992, s. 231. 
chrześcijanie” ( $\mathrm{z}$ innego wiersza Miłosza) sprzeniewierzają się wizji XIX-wiecznego poety, czy, przeciwnie, ich postawa jest - pośrednio - dalekim skutkiem warunku, jaki w utworze Norwida został narzucony Żydom ${ }^{37}$. Równie interesujące jednak (i może jeszcze bardziej kontrowersyjne) byłoby zastanowienie się, czy wiersz Norwida nie weryfikuje w nieco innym sensie wiersza Miłosza, a szerzej: sposobów ukazywania Żydów, w literaturze polskiej w ciągu ostatnich dwóch stuleci nierzadko obsadzanych w schematycznych rolach (niekoniecznie nacechowanych negatywnie); po Zagładzie należy do nich również obok patrioty - rola ofiary.

Wybrzmiewa to w przytoczonych na samym początku słowach Norwida o Panu Tadeuszu; oczywiście, słychać w tym fragmencie - świadectwie trzeźwej obserwacji - spiętrzoną ironię wymierzona przeciw retoryce wypowiedzi obwołujących poemat Mickiewicza epopeją narodową ${ }^{38}$ : nie dość bowiem - punktuje autor Vade-mecum że w utworze o rzekomo takich ambicjach dałoby się dopatrzeć zaledwie jednej poważnej postaci, to w dodatku nie jest ona Polakiem, lecz Żydem. Ale nawet uwzględniając dystans wpisany w ten komentarz, można przyjąć, że nazywając Jankiela „figura”, Norwid mimochodem zdiagnozował na dziesięciolecia pozycję Żydów w polskim zbiorowym imaginarium. Tak też rzecz ma się z wierszem Żydowie polscy: z pewnością nie jest to utwór konfrontacyjny, wypadałoby raczej uznać go za tekst koncyliacyjny, ale nadal nie narusza on status quo. I chyba na tym polega fenomen - tudzież problem - jego aktualności.

\section{Sztandary [KKK]}

Norwid pisał w jednym $z$ listów:

Jesteśmy żadnym s połe c zeń s twe m.

Jesteśmy wielkim sztandarem narodowy $\mathrm{m}^{39}$.

Dzisiaj, 200 lat od narodzin autora tych bezlitośnie prawdziwych słów, jesteśmy jeszcze bardziej „żadnym społeczeństwem” i jeszcze większym „sztandarem narodowym".

Sztandarem narodowym, czyli czym? Wyobrażenie narodu ma charakter subiektywny i mglisty. Do XIX wieku obywano się bez tego pojęcia w wyobraźni zbiorowej. W lipcu 1946, po pogromie kieleckim, Julian Tuwim, autor Rzeczy czarnoleskiej (wywodzący istotną linię poezji polskiej od Jana Kochanowskiego, przez Norwida), który niecały miesiąc wcześniej wrócił do Polski z wojennej tułaczki, pisał gorzko: „To, co się parę dni temu stało w Kielcach, jest zgrozą, hańbą, podłością, niezmyta brudna plamą na obliczu narodu (tj. czegoś niekonkretnego, ślepego, niewiadomego)" 40 .

Co ciekawe, podobne intuicje wyprowadzone $\mathrm{z}$ lektury wiersza Norwida pojawiają się w poemacie W. Wirpszy Mury (w: Czastkowa próba o człowieku i inne wiersze. Mikołów 2005, s. 25): „Poważny narodzie, powiedziano o / Żydach w poezji, a potem wewnątrz / Buchnęła powaga śmierci”. Warto odnotować, że pewne aspekty Norwidowskiej krytyki Pana Tadeusza komentował na łamach „Wiadomości Literackich” H. Pi ąt kow s k i (O „dodatniość sił nieustanna”. Norwid o „Panu Tadeuszu”. Trzy listy poety z r. 1866. „Wiadomości Literackie” 1925, nr 29. Na stronie: http://retropress.pl/wiadomosci-literackie/o-dodatniosc-sil-nieustannanorwid-o-panu-tadeuszu〈data dostępu: 15 II 2021〉). 
Michał Landy (1844-1861), ten, którego trzeba liczyć do rzeszy nazywanej „Żydowie polscy”, był synem kupca drzewnego, Henryka, uczniem warszawskiej Szkoły Rabinów oraz tamtejszego gimnazjum realnego, pasjonował się historią Polski $^{41}$; 8 IV 1861 wziął udział w akcie symbolicznego zbratania polsko-żydowskiego przy grobie Antoniego Eisenbauma ${ }^{42}$, a następnie w manifestacji związanej z pogrzebem sybiraka, Ksawerego Stobnickiego. Landy chwycił na chwilę krzyż (krzyż to symbol, jak sztandar nim jest), podjął go od innego upadającego demonstranta, kapucyna, trafionego kula przez wojska carskie - i zginą na Placu Zamkowym w Warszawie. Zdołał „bezbronne, jak Dawid, wyciągnać ramiona!”. Raniony, zmarł następnego dnia rano. Rodzina odzyskała ciało i pochowała bohatera na cmentarzu żydowskim. Stał się Michał Landy symbolem polsko-żydowskiej solidarności przed powstaniem styczniowym ${ }^{43}$.

Gest Landego to gest obywatela kraju nad Wisłą, który dla niego - niezależnie od rozbiorów i aktualnej nazwy, nadanej przez zaborcę - jest Polską. Żydowie polscy ginęli w Katyniu. Ginęli podczas powstania warszawskiego. Lecz ginęli także w pogromach międzywojnia, potem w Jedwabnem i innych miastach smierci ${ }^{44}$, i osamotnieni - podczas powstania kwietniowego, w getcie warszawskim, w 1943 roku.

To gest wolnego i myślącego człowieka. Krzyż nie był symbolem jego wiary, ale (w tym momencie) umownym znakiem jego polskości. Tuwim marzył, według tej samej logiki, o żółtej łacie - po Szoa - jako odznaczeniu rangi Virtuti Militari. Takie marzenia, marzenia obywatelskie, mające za podstawę bezinteresowną szlachetność, takie marzenia prawie nigdy się nie spełniają.

Co symptomatyczne, o sytuacji z roku 1861 wspomina Konstanty Gebert w rozmowie $\mathrm{z}$ Julia Popławska, zatytułowanej Mogliśmy być razem ${ }^{45}$. Stwierdza on m.in., że między ideałami Bundu a ideałami pierwszej „Solidarności” nie istniała wielka różnica oraz że Marek Edelman był tutaj „osobistym spinaczem” ${ }^{46}$. Publicy-

Tuwima z emigracji. Wyjatki z niepublikowanych listów do siostry. „Problemy” 1964, nr 7, s. 390. (Publikacja poprzedzona krótkim wstępem I. Tuwim.)

41 Wszystkie informacje za: R. Że brow ski, Landy Michał. Hasło w: Polski słownik judaistyczny. Dzieje, kultura, religia, ludzie. Oprac. Z. B or zy miń s ka, R. Że brow s ki. T. 2. Warszawa 2003. Antoni E is e n ba um, urodzony w Warszawie w roku 1791, zmarł tamże w roku 1852, maskil, pisarz, działacz społeczny i oświatowy. Wydawca pierwszego w Polsce polsko-żydowskiego czasopisma „Dostrzegacz Nadwiślański” (1823-1824). Kierował warszawską Szkołą Rabinów. Zbratanie polsko-żydowskie przy jego grobie - 8 IV 1861 - nazywane bywa manifestacją najbardziej spektakularną. Zob. R. Że brow ski, Eisenbaum Antoni. Hasło w: Polski słownik judaistyczny, t. 1.

43 Rodzina Michała Landego także działała na rzecz polskiej niepodległości: brat Szoel został „wydalony z Warszawy za udział w organizowaniu manifestacji patriotycznych (czerwiec 1861)", brat Aleksander (pseud. Niedzielski) „walczył w powstaniu (ranny pod Radziwiłłowem, 2 VII 1863), zginął w Górach Świętokrzyskich”; ojciec, Henryk, „zajmował się zbieraniem funduszy na cele narodowe, aresztowany, uniknął jednak zesłania" (Ż e b r o w s ki, Landy Michat, sv). Formuła Try c zy k a z jego książki pod takim tytułem (op. cit.). Zob. moje omówienie tej monografii pt. Ściegi i fastrygi. „Narracje o Zagładzie” 2017, nr 3. Rozmowa pochodzi z archiwum Muzeum Historii Żydów Polskich POLIN, została nagrana w 2009 roku, a jej pierwodruk ukazał się w „Midraszu” (2013, nr 3).

46 Mogliśmy być razem. Z K. Ge berte m rozmawia J. Popławska. Cyt. Z: „Midrasz” 2019, nr 4, s. 43-45. Gebert prezentuje stanowisko Edelmana, który w latach osiemdziesiątych XX wieku przeciwstawiał się władzom PRL-u: „Nie można oddawać hołdu powstańcom z getta pod auspicjami tych, którzy są zaprzeczeniem tego, o co getto walczyło" (jw., s. 45). 
sta, posługujący się także pseudonimem Dawid Warszawski, przywołuje manifestacje obywatelskiej solidarności polsko-żydowskiej w latach 1983 i 1988 na terenie byłego getta w Warszawie. Tak komentuje Gebert sytuację tuż po stanie wojennym (1983), a potem tę z 1988 roku:

To było bardzo ważne dla nas, polskich Żydów. Dostaliśmy empiryczny dowód, że nie byliśmy sami. Myślę, że było to ważne też dla nieżydowskich Polaków: pokazanie samym sobie, jak potrafimy być przyzwoici i dzielni. Taka sytuacja wydobywa z ludzi, co najlepsze, a to nie może trwać długo. Weźmy pogrzeb poległych z 1861 roku. Pełna jedność warszawiaków przeciwko caratowi. Ale wcześniej mieliśmy wojnę żydowską w polskiej prasie, a później mamy rozwój nowoczesnego antysemityzmu. Podobnie $\mathrm{z}$ naszymi manifestacjami, one nie zapobiegły bujnemu rozkwitowi antysemityzmu w społeczeństwie niezależnym i w wolnej Polsce. Zapobiec nie mogły, ale pokazały nam, jak może być lepiej, na co nas stać, jeśli potrafimy się zdobyć na przyzwoitość i odwagę ${ }^{47}$.

Walter Benjamin nazwałby zapewne owe krótkie chwile zbiorowej solidarności „drobnymi rysami w ciagłej katastrofie” 48 .

\section{Dlaczego Żydowie polscy są wierszem-inicjałem? Gramatyka [KKK]}

Bronka Szawara, poetka ocalała $z$ ludobójstwa na Zamojszczyźnie, powiada: „a oni do lasu uciekli, nasze ludzie i Żydowie nasze" ${ }^{49}$. I ta formuła daje do myślenia. Słowo „Żydowie” należy do porządku biblijnego, Norwidowego, jest pełne szacunku dla „poważnego narodu”, ,jak pomnika strzaskanego na Wschodzie”, ale też zapowiada. Wiersz Norwida Żydowie polscy zapowiada los Żydów polskich. „Żydowie polscy” sa jak „monarchowie polscy” - formuła tak brzmiąca podkreśla rangę, wskazuje na szczególną godność: królewską, Dawidową, na odrębność i mądrość. Koherencja rzeczownika i określającego go przymiotnika są tu ściśle respektowane.

„Żydowie” stanowi przecież przeciwwagę dla „Żydy” ${ }^{50}$, neutralne pozostaje słowo „Żydzi”.

Inaczej w narracji chłopki-poetki. „Żydowie nasze” to formuła wewnętrznie pęknięta. Formuła spoza decorum. Być może, celowo, być może, nie. Szacunek przywiązany do rzeczownika „Żydowie”, owo podkreślenie szczególnego statusu ludzi i osób należących do narodu mesjańskiego, pęka w zderzeniu z przymiotnikową formą żeńsko-rzeczową. Ten dysonans jest sednem przyzwolenia na Zagładę i zdziwienia Zagładą. („Żydy nasze” byłoby koherentne; Socha z filmu $W$ ciemności Agnieszki Holland krzyczy: „Moje Żydy”, gdy wychodzą ocaleni z lwowskich kanałów.) Żydowie nasze - (szły na rzeź jak) krowy nasze, (gwałcone były jak) kobiety nasze, (rzucane były główkami o mur jak) dzieci nasze. Zagłada bierze się z męskiego świata zabijania (nie tylko na wojnie). Zagłada nie oszczędza kobiet, dzieci, zwierząt. Jest męskoosobowa. Nie dopuszcza zdrobnień ani spieszczeń (nawet chłopięcych): Dawidka-Żydka, Dzieciątka-Jezus, krówki z cielątkiem.

48 „Drobne rysy $w$ ciagłej katastrofie...” Obecność Waltera Benjamina $w$ kulturze wspótczesnej. Red. A. Zeidler-J a nis zew ska. Warszawa 1993.

49 Cyt. za: A. J a n k o, Mała Zagłada. Kraków 2015, s. 130.

50 Zob. K. Ku c zy ńs ka - K o s c h a ny, „Vse poèty židy”. Antytotalitarne gesty poetyckie i kreacyjne wobec Zagłady oraz innych doświadczeń granicznych. Poznań 2013, passim. 
Między tytułem Żydowie polscy a formuła „Żydowie nasze” jest przepaść dwu narracji: tej toczącej się od wiersza Cypriana Norwida i tej idącej od słów Bronki Szawary. Obydwie formuły sa prawdą o antysemityzmie: pierwsza - pogromowa, druga - zagładową.

„Żydy parszywe”, „bić Żyda” - są tych formuł odwrotnością. Są wezwaniem do nienawiści.

\section{Prywatny, europejski [KKK]}

Powtórzyłam w tytule tej całostki - po części - tytuł artykułu pióra Juliusza Wiktora Gomulickiego Norwid - poeta europejski, opublikowanego w „Nowej Kulturze” w roku 1958 (nry 21 i 22, z 25 V i 1 VI) w 75 rocznice śmierci poety.

Norwida czytać zaczęłam w siódmej klasie, w roku 1983, i czytam - nieprzerwanie - do dziś. (Od razu też, w tej samej klasie, zaczęłam kłócić się z moją ówczesną polonistka, panią Leokadią Winiarska, że Norwid jest lepszy od Mickiewicza; a ona powiedziała tylko: dobrze, porozmawiamy, kiedy przeczytasz całego). Więc czytałam. Najpierw tomik kieszonkowy, mojej Mamy. Potem duże wydania jednotomowe. Później - niebieskie wydanie 5-tomowe Pism wybranych. Wreszcie - 10-tomowe, w płóciennej oprawie ( $\mathrm{z}$ jedenastym tomem komentarzy), z 1971 roku w opracowaniu Gomulickiego. Przez wiele lat, w liceum i na studiach budziłam się o czwartej rano i zaczynałam dzień od głośnej lektury Norwida, wszystkich pism, po kolei. I od nowa. Nie ma dzisiaj innego poety, którego wyimków znałabym więcej na pamięć i którego słowa równie często ratowałyby mnie z życiowych i narodowych opresji. Nie sa to nawet ci poeci, Rainer Maria Rilke i Julian Tuwim, którym poświęciłam całe książki, ani te poetki - Anna Pogonowska i Irena Tuwim - których wybory wierszy przygotowałam do druku w osobnych tomach ${ }^{51}$. To Jak Norwida (fragment poematu A Dorio ad Phrygium) recytowałam przed Stefanem Treuguttem na olimpiadzie polonistycznej w Warszawie, w kwietniu 1989 (inni Polacy siedzieli wtedy przy Okrągłym Stole).

Znam, oczywiście, rozprawy, znakomite, porównujące Norwida z Téophile’em Gautier (Macieja Żurowskiego) ${ }^{52}$ czy z Stéphane'em Mallarmé (Piotra Śniedziewskiego) ${ }^{53}$; znam studia, równie świetne, traktujące o inności Norwidowskiego romantyzmu (Zofii Stefanowskiej) ${ }^{54}$, o starości (także kulturowej) tego poety (Krzysztofa Trybusia) ${ }^{55}$, o jego umiłowaniu Grecji (Macieja Junkierta) ${ }^{56}$. Zdaje sobie sprawę, że równocześnie $\mathrm{z}$ francuskim vers libre powstawał ten system (czy raczej

K. Ku c zyń ska - Ko s c ha ny: Rilke poetów polskich. Wyd. 2, uzup. i poszerz. Toruń 2017; Pęknięcie. Łódź 2021. - A. P o g o n o w s ka, Wiersze (nie)zapomniane. Wybór, posł. K. K u c zy ń s k a - Ko s ch a ny. Lublin 2018. - I. Tuw i m, Wiersz o najważniejszym wierszu. Wybór, wprowadz. K. Kuczyńska-Kos chany. Lublin 2020.

52 M. Żurows ki, Norwid i Gautier. W zb.: Nowe studia o Norwidzie. Red. J. W. G o m uli cki, J. Z. Jakubowski. Warszawa 1961.

53 P. Śn i edzi ew s ki, Mallarmé - Norwid. Milczenie i poetycki modernizm we Francji oraz $w$ Polsce. Poznań 2008. 
styl) wersyfikacyjny, który Maria Dłuska nazwała później emocyjnym albo norwidowskim.

Ale dopiero pisząc te słowa, uświadomiłam sobie tak mocno, tak jednoznacznie, że Norwid był pierwszym wielkim poetą europejskim, którego czytałam. Ewa Bieńkowska twierdzi, iż sprawa Dreyfusa we Francji spowodowała narodziny grupy ludzi, którą nazywa się intelektualistami ${ }^{57}$. W Europie Środkowej to może raczej dysydenci. Tak czy inaczej, niezależni myślowo, otwarci, dobrze wykształceni, cechujący się odwagą cywilną - w Polsce - mają za sobą często uważną i nieuprzedzoną lekturę Norwida.

\title{
Podsumowanie
}

Dwugłos na temat wiersza Żydowie polscy, celowo pozbawiony ujednoznaczniającej wymowy, a miejscami proponujący wręcz antagonistyczne odczytania utworu, na swój sposób wpisuje się w Norwidowską ideę i praktykę mijania się form - perspektyw, realizuje imperatyw uwzględniania - o czym mowa choćby w Ogólnikach - wielu aspektów danego zjawiska, wydobywających jego komplikację. Chciałyśmy bowiem pokazać, że od przyjętego stylu lektury, m.in. od stopnia podejrzliwości wobec tekstu, zależy możliwość opisania tym wierszem różnych wymiarów relacji polsko-żydowskich, które w istocie są przecież także relacjami polsko-polskimi i nie zawsze przybieraja postać dialogu, a również w nim mieści się skala światłocienia.

\author{
Abstract \\ ANITA JARZYNA University of Łódź \\ ORCID: 0000-0001-7527-6085 \\ KATARZYNA KUCZYŃSKA-KOSCHANY Adam Mickiewicz University, Poznań \\ ORCID: 0000-0002-1671-2278
}

\begin{abstract}
NORWID AND STANDARDS CONTRIBUTIONS TO INTERPRETATION AND RECEPTION HISTORY OF THE POEM "ŻYDOWIE POLSCY" ("POLISH JEWS")-A TWO-VOICE APPROACH
\end{abstract}

The article falls into in a series of comments on a famous Cyprian Norwid's poem Żydowie polscy (Polish Jews. 1861). The authors, referring to the poem's interpretations to this day, focus first and foremost on the potential of its actualisation in the context of the contemporary reflection on the Polish-Jewish relationships, and in effect they turn attention to the risk of instrumentalisation that this mode of analysis brings about. A flagrant example of such practices is the reception of the text that took place in connection with the celebration of the poet's $50^{\text {th }}$ death anniversary in 1933 in the papers of disparate worldview and political orientation (from "Myśl Narodowa" 〈"National Thought"〉 to "Nasz Przegląd" 〈"Our Review"〉). The analysis of the statements allows to settle that the poem's variously profiled clarifications reveal its ambiguous reading in the context of Norwid's alleged attitude to Polish Jews and their place in citizen society, and in our perspective also induces to verify the modes of their presentation in the Polish imaginarium.

57 E. Bi eń k ow s k a, Sprawa Dreyfusa. W: Spór o dziedzictwo europejskie: między świętym a świeckim. Warszawa 1999. 